\title{
A practical perspective on ulvan extracted from green algae
}

\author{
Anabela Alves • Rui A. Sousa • Rui L. Reis
}

Received: 9 February 2012 / Revised and accepted: 27 June 2012 / Published online: 17 July 2012

(C) Springer Science+Business Media B.V. 2012

\begin{abstract}
Researchers have many times turned their attention to nature and biological processes to develop novel technologies and materials. In a medical perspective, nature-based products are believed to be a strategic alternative approach to the use of fully synthetic materials, particularly in the design of medical devices. In the past decades, marine organisms have become the focus of considerable attention as potential sources of valuable materials. The sustainable exploitation and valorisation of natural marine resources constitutes a highly attractive and strategic platform for the development of novel biomaterials, with both economic and environmental benefits. In this context, algae are known to synthesise large quantities of polysaccharides and are well established sources of these particularly interesting molecules, many of which are known for their applicability in the design of biomaterials. Agar, carrageenan and alginates are some of the most known examples, and their uses can range from food to biomedical
\end{abstract}

R. A. Sousa $\cdot$ R. L. Reis

3B's Research Group-Biomaterials, Biodegradables

and Biomimetics, Headquarters of the European Institute

of Excellence on Tissue Engineering and Regenerative Medicine,

University of Minho,

AvePark, Zona Industrial da Gandra, S. Cláudio do Barco,

4806-909 Caldas das Taipas,

Guimarães, Portugal

A. Alves $\cdot$ R. A. Sousa $\cdot$ R. L. Reis

ICVS/3B's-PT Associated Laboratory,

Braga/Guimarães, Portugal

Present Address:

A. Alves $(\bowtie)$

3B's Research Group-Biomaterials, Biodegradables

and Biomimetics, Headquarters of the European Institute

of Excellence on Tissue Engineering and Regenerative Medicine,

University of Minho,

AvePark, Zona Industrial da Gandra, S. Cláudio do Barco,

4806-909 Caldas das Taipas,

Guimarães, Portugal

e-mail: anabela.pinto@dep.uminho.pt applications. However, few of the world's available seaweed species are used commercially. Among the three main divisions of macroalgae (Chlorophyta, Phaeophyta and Rhodophyta), the green algae remain largely unexploited in this biomedical arena. While the demand for novel materials and technologies increases, so does the research of unexploited marine green algae including its unique polysaccharide ulvan.

Keywords Green algae · Ulvan · Polysaccharide · Biopolymer · Biomaterial

\section{Introduction}

The world's oceans are a rich environment containing over 300,000 invertebrates and algal species (as cited in Pomponi 1999). These species survive and live within complex communities and in close association with other organisms. This diversity of living systems and habitats defines the basis of the wide variety of chemical classes typical of marinederived molecules. Some organisms withdraw their rich chemistry from dietary sources, whilst others synthesise these compounds de novo (Cannell et al. 1998). Molecular diversity represents a vast and valuable chemical library, including saccharides, pigments, phenols or peptides, among others, which, together, are estimated to possess a potential market value of several billion dollars (Pomponi 1999).

In this scenario, marine algae, rich in different compounds of interest, are used in several industrial application contexts totalizing a consumption of 3.5 million tonnes of algae per year worldwide (Jensen 1993). The importance of these organisms and their constituents to humanity has justified intense research work; however, the full potential of algae molecules is yet to be unveiled.

Marine algae can be divided in three main groupsred (Rhodophyceae), brown (Phaeophyceae) and green 
(Chlorophyceae) - classified on the basis of their photosynthetic pigments (Barsanti and Gualtieri 2006). These algae also differ on the type of storage material and cell-wall polysaccharides (Barsanti and Gualtieri 2006; Bocanegra et al. 2009). A large fraction of the world commercially exploited polysaccharides are of marine origin, namely alginate, agar and carrageenan (Jensen 1993; Lahaye and Axelos 1993; Michel and Macfarlane 1996). Within this context, green algae are still rather unexploited. Although they have been used in food for many centuries, it was the discovery of an important constituent of green algae, ulvan, which dramatically increased interest in these algae. Focused research on ulvan's characteristics and applicability, therefore, is required in order to grasp the full range of its capabilities and boost the industrial interest in green algae.

\section{Historical outline}

Classification of alga has not always been an easy task. Complexity is enhanced when recent genetic studies reveal that Chloropelta, Enteromorpha and Ulva in fact belong to the same genus (Hayden et al. 2003).

As the work with brown and red macroalga evolved to a well-established field of knowledge, the interest in green algae and especially its polysaccharides had a late and bumpy start. An interesting and complex polysaccharide composed of sulphate ester, uronic acids and xylose, rhamnose and glucose residues was identified in the early 19401950s. This pioneer work was, however, interrupted for several years due to the Second World War (Brading et al. 1954). In these early studies, Brading and co-workers (1954) already identified a possible structure present in this sulphated polysaccharide as $-\mathrm{CH}(\mathrm{OH})-\mathrm{CH}\left(\mathrm{O}-\mathrm{SO}_{3} \mathrm{Na}\right)-\mathrm{CH}$ $(\mathrm{OH})-$. However, no evidence was found on what concerns the true position of the sulphate groups on the polysaccharide structure, although it seemed possible that they should be linked to glucose or rhamnose (Brading et al. 1954). This was also one of the first times rhamnose was identified as being part of an algal polysaccharide. In 1962, McKinnell and co-workers (McKinnell and Percival 1962b) found evidence that the sulphate groups were in fact linked to rhamnose. Ten years later, Abdel-Fattah and Edrees (1972) concluded on the heteropolysaccharidic nature of this polysaccharide, composed of particular entities of oligosaccharides of rhamnose and uronic acids composing its backbone, intercalated with sequences involving glucose, arabinose and xylose. The particularly acidic nature of the polysaccharide was assigned to the presence of glucuronic acids (Abdel-Fattah and Edrees 1972). In these early years, researchers were struggling with the identification and characterization of this unusual and complex polysaccharide. Extracts were obtained from different green algae genus and species and were characterised and compared between each other. Despite the fact that different researchers were extracting a polysaccharide from different genus and species of green algae, through diverse extraction methodologies, they all came to similar conclusions and agreed that the water-soluble polysaccharide from green algae was mainly composed of uronic acid and sulphated rhamnose with residues of diverse sugars, like xylose and glucose (AbdelFattah and Edrees 1972; Brading et al. 1954; Gosselin et al. 1964; Lahaye and Axelos 1993; McKinnell and Percival 1962a, b; Percival and Wold 1963; Ray and Lahaye 1995b). It was only in 1993 that the designation "ulvan" was proposed (Lahaye and Axelos 1993). It is now generally accepted that ulvan designates a class of sulphated polysaccharides mainly composed of glucuronic acid and sulphated rhamnose (Ray and Lahaye 1995b). The important discovery that iduronic acid was a constituent of the ulvan backbone was only made in 1997 (Quemener et al. 1997).

There is still a long way to go until the true nature of this polysaccharide is unravelled. However, in the last decade, research on ulvan has evolved as the knowledge on its occurrence and physiological function, chemical composition, polysaccharide conformation and properties has improved. This knowledge is now driving research a step forward towards the application development of this polysaccharide.

\section{Physiological function}

Marine algae are simpler organisms compared to land plants; however, they produce larger quantities of polysaccharides (Wood 1974). These polysaccharides are strikingly different with those found in higher plants, especially on what concerns the presence of sulphate groups and unusual sugar residues, high content of ionic groups, high water solubility and unique rheological properties (Jensen 1993; Michel and Macfarlane 1996; Popper et al. 2011; Wood 1974). This results in a range of distinctive characteristics and is the basis of their widespread industrial applicability.

In general, green algae are composed of $\sim 11 \%$ protein, $\sim 36 \%$ carbohydrate, $\sim 53 \%$ ashe and are rich in minerals like calcium, iron, phosphorous and chloride (Castro-González et al. 1996). Carbohydrates include cell-wall water-soluble sulphated ulvan, alkali-soluble hemicellulosic $\beta(1,4)$-D-glucuronan and $\beta(1,4)$-D-glucoxylan and amorphous $\alpha$-cellulose with xylose residues (BobinDubigeon et al. 1997b; Lahaye et al. 1997; Lahaye and Ray 1996; Ray and Lahaye 1995a, b).

Ulva spp. possess a characteristic blade-shaped frond, twocell thick, with no tissue differentiation (Bobin-Dubigeon et al. 1997b). However, their cell walls are well organised in layers and rich in polysaccharides (Bobin-Dubigeon et al. 
1997b; Popper et al. 2011). Ulvan is mostly homogeneously distributed throughout the frond being more predominant within the intercellular space and in the fibrillar wall (BobinDubigeon et al. 1997b). Within this cell wall moiety, it is suggested that ulvan may be arranged in a bead-like structure, stabilised by cell wall proteins or strong physical interactions (Robic et al. 2009b). It is well known that boron is accumulated in algae, in the form of boric acid in green algae, and it was suggested that complexes with carbohydrates (Chuda et al. 1997). Given that ulvan is able to gel in the presence of boric acid, in a reaction mechanism mediated by calcium ions (Lahaye and Axelos 1993), it is easy to hypothesise that this polysaccharide may be present in green algae cell wall in the form of a gel, cross-linked by boron ions.

As far as the physiological function of ulvan within the cell wall goes, the literature is rich in hypotheses (e.g., Andrieux et al. 1998; Bobin-Dubigeon et al. 1997b; de Reviers and Leproux 1993; Lahaye et al. 1998; Paradossi et al. 1999; Popper et al. 2011; Quemener et al. 1997; Wood 1974). In general, the presence of sulphated polysaccharides can be associated with the organism's adaptation to ionic environments; this is true for marine plants and algae (seawater) as well as for vertebrates (physiological saline serum) (Popper et al. 2011). Therefore, ulvan, as part of the cell wall of green algae, would possess osmotic functions, including a role on ionic balance or on the prevention of algae desiccation due to its highly hygroscopic nature (Paradossi et al. 1999; Wood 1974). On the other hand, ulvan appears to inhibit the activity of cellulase, which indicates a protective role towards cell wall amorphous $\alpha$-cellulose, protecting it from marine bacterial attack (Andrieux et al. 1998; BobinDubigeon et al. 1997b; Lahaye et al. 1998). This protective function is also related with the fact that ulvan is associated with the low porosity of green algae (Bobin-Dubigeon et al. 1997b; Lahaye et al. 1998). Furthermore, ionic polysaccharides may be involved in mechanical regulation, spore release and adhesivity (de Reviers and Leproux 1993; Popper et al. 2011). The presence of acidic moieties in the ulvan polysaccharidic chain, particularly glucuronic and iduronic acid, may indicate that this polysaccharide is also involved in cell wall cohesion, in parallelism with mammalian glycosaminoglycans rich in uronic acids (Lahaye et al. 1998; Quemener et al. 1997).

\section{Extraction of ulvan from green algae}

This section is intended to provide guidance to those interested in extraction of natural products, especially from green algae. Success in working with nature-derived materials is very well summarised by Cannell and co-workers (Cannell et al. 1998): "One should always keep an open mind, expect the unexpected, use as many methods for purification as possible, and save all fractions."

The overall procedure to obtain polysaccharides from green algae can be divided in several different steps:

- Selection, collection, and identification of the raw material;

- Algae stabilisation and grinding;

- Extraction and purification;

- Precipitation; and

- Drying.

When working with nature-derived materials, one should always recognise and consider the inherent variability of extracted molecules from sources of natural origin (Jani et al. 2009); this can be due to varying extraction methodologies, seasonality or algae species and ecophysiology (Abdel-Fattah and Edrees 1972; Devaki et al. 2009; Hernández-Garibay et al. 2010; Lahaye and Axelos 1993; Robic et al. 2008, 2009b, c; Yamamoto 1980). One practical example is the variability of the obtained polysaccharide related with source as reported by Lahaye and Axelos (1993), when comparing the rheological behaviour of a polysaccharide obtained from Ulva spp. with one obtained from Ulva lactuca.

Selection, collection, and identification of the raw material

The first step in extraction of algae-derived materials involves the selection, collection and identification of the raw material. During these initial stages, one should try to answer some questions:

- What is the rationale for the extraction of a particular polysaccharide?

- What is the most accessible source of algae available suitable for the extraction of such polysaccharide?

- Can a compromise between yield and purity be obtained by appropriately selecting the algae species?

- Is it possible to have access to large quantities of the selected algae species?

The answer to these questions defines the basis of any future extraction procedure and allows the establishment of good criteria for potential industrial applications of ulvan.

In order to obtain the selected algal raw material, it is possible to collect it in loco, culture it or obtain it through specialised enterprises (Table 1). To address this issue, one should keep in mind that besides source dependence, crosscontamination by other organisms, habitat, geography and seasonality are relevant factors that influence and further complicate the work with marine natural products (Cannell et al. 1998; Lahaye and Robic 2007). Furthermore, among the biggest challenges when working with algae is their identification, which often can only be done correctly by 
Table 1 Examples of companies specialised in the commercialization of algae

\begin{tabular}{|c|c|c|c|c|}
\hline Company & Location & Algae & Culture system & Website \\
\hline $\begin{array}{l}\text { Sinaloa Seafields } \\
\text { International Inc. }\end{array}$ & California, USA & Ulva sp. & $\begin{array}{l}\text { Algae culture in non-arable } \\
\text { land with sea water irrigation }\end{array}$ & http://www.sinaloa-seafields.com/home/ \\
\hline Atlantic Mariculture Ltd. & $\begin{array}{l}\text { Grand Manan } \\
\text { Island, Canada }\end{array}$ & Ulva sp. & $\begin{array}{l}\text { Local harvest of native sea } \\
\text { vegetables }\end{array}$ & http://organicdulse.com/ \\
\hline Setalg & Pleubian, France & Ulva lactuca & Harvest on algae fields & http://www.setalg.com/ \\
\hline $\begin{array}{l}\text { Mariculture Technologies } \\
\text { International, Inc. }\end{array}$ & Florida, USA & Ulva sp. & Local harvest (wild-collected) & http://www.mariculturetechnology.com/ \\
\hline
\end{tabular}

an expert phycologist (Cannell et al. 1998; Lahaye and Robic 2007).

Algae can be obtained by harvesting natural seaweed beds or by algaculture (Michel and Macfarlane 1996). The availability of green algae allows a sustainable exploitation of this resource (Pomponi 1999). They are often involved in algal blooms with detrimental health and socio-economic impact (Charlier et al. 2007; Lahaye and Axelos 1993; Morand and Briand 1996). These algal blooms occur in nutrient-rich waters, stimulated by human activity in coastal regions (Charlier et al. 2007; Lahaye and Axelos 1993; Morand and Briand 1996). Partial or total utilisation of these algae and particularly of its polysaccharide ulvan would alleviate the effect of accumulation and elimination of these deleterious biomasses. Furthermore, it is easily cultured in (semi-) artificial conditions, both in-the-sea and land-based conditions, alone or in integrated systems (Barsanti and Gualtieri 2006; Bruhn et al. 2011; Matsuo 2004; Msuya and Neori 2008). These facts make green algae easily accessible to research work and application development.

\section{Algae stabilisation and grinding}

The first extractions of polysaccharides from green algae usually started with washing of algae prior to thermal drying (Bocanegra et al. 2009). Nowadays, relevant advances in seaweed and hydrocolloid industries reveal other alternatives to algae stabilisation treatments prior to polysaccharide extraction. Robic and co-workers (Robic et al. 2008) have studied the effect of different green algae pre-treatments, including freezing, drying methods, brining and dry salting. These different algae stabilisation treatments have a marked effect on the final yield of extraction and on ulvan's physicochemical traits, including molecular weight and viscosity. Higher yield is obtained for algae brined for 7 weeks; however, higher molecular weight and viscosity is obtained for frozen and freeze-dried algae (Robic et al. 2008). These results emphasise the need for a concise evaluation of the final application of the extracted polysaccharide and the expected cost and efficiency of the extraction procedure. Furthermore, it is important to note the effect of these pretreatments on the chemical composition of the polysaccharide, in particular due to polysaccharide modification or even degradation (Robic et al. 2008).

Extraction and purification

Before and after extracting the polysaccharide per se, one must be aware of interfering substances that can be coextracted with the molecule of interest and of other contaminants introduced during extraction, etc. These substances and contaminants can either affect purity of the extract or interfere with biological responses towards the polysaccharide (Cannell et al. 1998).

Removal of photosynthetic pigments (de-colouring) and lipids (de-fatting) may be considered as the first steps of purification. De-colouring and de-fatting can be achieved by different methods, including supercritical extraction, soxhlet extraction or simple immersion in organic solvent (Brading et al. 1954; Cannell et al. 1998; Gosselin et al. 1964; McKinnell and Percival 1962a,b; Percival and Wold 1963; Siddhanta et al. 2001). Being considered a green technology, the use of supercritical fluids avoids or reduces the use of organic solvents. However, this is an expensive technology, and the use of organic solvents is still more effective and widely used, both for de-colouring and de-fatting (Kitada et al. 2008). In this regard, soxhlet extraction is an old but effective technique (Luque de Castro and GarciaAyuso 1998). Different organic solvents may be used to remove pigments, including acetone (Brading et al. 1954; McKinnell and Percival 1962a; Percival and Wold 1963; Ray 2006), ethanol (Alves et al. 2010; McKinnell and Percival 1962b; Ray 2006; Xiong et al. 2010), methanol (Gosselin et al. 1964; Ray 2006), petroleum ether (Chattopadhyay et al. 2007; Jani et al. 2009) or chloroform (Jani et al. 2009). However, McKinnell and Percival (1962b) found that the best solvent to remove colouring matter from green algae is $85 \%$ aqueous ethanol. Kitada and co-workers (2008) also found ethanol a more effective solvent to extract pigments, when compared to acetone; furthermore and considering safety issues, ethanol presents lower toxicity compared to acetone. On the other hand, treatment of algae with ethanol prior to polysaccharide extraction increases the total sugar content of the extract and decreases the presence of minor sugars and 
glucose on the final polysaccharide extract (Ovodov 1975; Robic et al. 2009b).

Effective extraction of a polysaccharide of natural origin is mainly dependent on its solubility, stability and functional group considerations (Cannell et al. 1998). Being a watersoluble polysaccharide, ulvan can be effectively extracted with water (Alves et al. 2010; Ray and Lahaye 1995b). Some studies report that hot water extraction results in good extraction yields (McKinnell and Percival 1962b; Robic et al. 2009b; Yamamoto 1980). High temperatures, in the range of $80-90{ }^{\circ} \mathrm{C}$, allow the extraction of higher molecular weight polysaccharides (Yamamoto 1980). However, above $100^{\circ} \mathrm{C}$, lower viscosity is detected, when compared with ulvan extracted at $80-90{ }^{\circ} \mathrm{C}$ (Yamamoto 1980), which may reflect some instability of the polysaccharide extracted in this range of temperature (Lahaye and Robic 2007). Ulvan can also be successfully extracted with sodium carbonate solution (Brading et al. 1954), calcium chelating agents, such as ammonium oxalate or ethylenediaminetetraacetic acid (Abdel-Fattah and Edrees 1972; Hernández-Garibay et al. 2010; Ray 2006; Robic et al. 2009b) or acidic solutions (Abdel-Fattah and Edrees 1972; Gosselin et al. 1964; Hernández-Garibay et al. 2010; Lahaye et al. 1998; Robic et al. 2009b). The use of calcium chelating agents facilitates ulvan extraction by means of sequestering calcium ions and disrupting chemical bonds formed by ulvan in the presence of calcium ions within the cell wall of green algae (Abdel-Fattah and Edrees 1972; Robic et al. 2009b). On the other hand, decrease of $\mathrm{pH}$ of the extraction media will de-stabilise aggregates of ulvan within the cell wall, increasing extraction yield (Robic et al. 2009b). The use of different solvents to extract ulvan will result in extracts with varying physicochemical and biological properties (Abdel-Fattah and Edrees 1972; Hernández-Garibay et al. 2010; Ray 2006; Robic et al. 2009b; Siddhanta et al. 2001). In this regard, it is important to define the objective of the extraction and the final properties expected from the resulting polysaccharide.

Being a cell wall material, common contaminants of this polysaccharide are amino acids and peptides (Brading et al. 1954; Lahaye et al. 1999; McKinnell and Percival 1962b). In fact, direct extraction with hot aqueous solutions will result in an extract mixture of polysaccharides, proteins, polyphenols and pigments (Béress et al. 1993). Methods to remove nitrogenous materials include enzymatic treatment with proteinase $\mathrm{K}$ (Alves et al. 2010) or precipitation with trichloroacetic acid (McKinnell and Percival 1962b). Besides nitrogenous material, McKinnell and Percival (1962b) found evidence of contamination by starch-like materials in hot water extracts. However, this starch can be effectively removed with salivary $\alpha$-amylase (Costa et al. 2012; Love and Percival 1964; McKinnell and Percival 1962b; Percival and Wold 1963). Smaller molecular weight contaminants, including those responsible for odour and also colour can be removed with activated charcoal (Alves et al. 2010; Cannell et al. 1998; Gosselin et al. 1964); hydrogen peroxide can also be used as a de-colouring agent (Yang and Zhang 2009). Further purification may be achieved by other methods, including dialysis or even through final precipitation (Ovodov 1975).

\section{Precipitation and drying}

In general, water-soluble polysaccharides are removed from solution by precipitation with organic solvents. In the particular case of ulvan, it precipitates from aqueous solutions with ethanol or acetone, usually four volumes of the chosen organic solvent (Alves et al. 2010; Gosselin et al. 1964; Siddhanta et al. 2001). Ethanol precipitation allows the separation of the polysaccharide from low molecular ethanol-soluble compounds (Béress et al. 1993) and the removal of some pigments (Lahaye 1991); thus it is considered as a purifying step as well (Elboutachfaiti et al. 2011; Ovodov 1975; Tavernier et al. 2008).

Extracted polysaccharide can be dried by different methods. However, Jani and co-workers (2009) highlight the need to apply low temperature or vacuum on drying in order to avoid degradation of the polysaccharide.

\section{Yield}

Cell wall carbohydrate content of green algae ranges from 38 to $54 \%$, and ulvan content may vary between 18 and $29 \%$ (Kaeffer et al. 1999; Lahaye and Robic 2007). Yield of extraction of ulvan varies between 1.2 to $27.5 \%$ and the maximum extraction efficiency is in the range of $70 \%$ (Abdel-Fattah and Edrees 1972; Alves et al. 2010; Chattopadhyay et al. 2007; El-Baky et al. 2009; Gosselin et al. 1964; Hernández-Garibay et al. 2010; McKinnell and Percival 1962b; Paradossi et al. 1999; Percival and Wold 1963; Ray 2006; Ray and Lahaye 1995b; Robic et al. 2008, 2009b, c; Siddhanta et al. 2001; Yamamoto 1980).

In general, a decrease in algae particle size will increase the yield of extraction (Robic et al. 2009b). This is also influenced by factors including algae pre-treatments, solvent used to extract the polysaccharide per se, number, duration and temperature of extractions, purification methodologies, algae species and seasonality (Abdel-Fattah and Edrees 1972; Hernández-Garibay et al. 2010; Lahaye and Robic 2007; Percival and Wold 1963; Robic et al. 2008, 2009b, c; Siddhanta et al. 2001; Yamamoto 1980).

\section{Storage}

As polysaccharides, and ulvan in particular, are hydrophilic and readily uptake water from the atmosphere, it is 
recommended to store the extracted polysaccharide in a dry environment, ideally on desiccators, to avoid moisture uptake and degradation (Alves et al. 2010; Jani et al. 2009).

\section{Chemical structure and conformation}

Ulvan has been identified as being a sulphated single polydisperse heteropolysaccharide composed of variable amounts of uronic acids, including glucuronic and iduronic acids alternating with neutral sugar moieties, such as rhamnose, xylose and glucose residues, connected by $\alpha$ - and $\beta$ $1 \rightarrow 4$ bonds (Brading et al. 1954; Lahaye 1998; Lahaye et al. 1997, 1998, 1999; Lahaye and Ray 1996; Percival and Wold 1963; Quemener et al. 1997). This polysaccharide accounts for $18-29 \%$ of the carbohydrate fraction of green algae (Kaeffer et al. 1999). McKinnell and Percival (1962b) provided important insights on the structure of this polysaccharide by demonstrating that the sulphate groups were in fact linked to rhamnose, possibly in position 2; they suggested possible branching of the heteropolysaccharide, and uronic acid residues are pointed as possible end groups, being these attached to position 4 in rhamnose (McKinnell and Percival 1962b). Later on, it was proposed that sulphate groups may be linked to C-2 or C-3 in rhamnose and there is evidence of the presence of some sulphated xylose, with sulphate occurring in position 2 (Percival and Wold 1963; Ray and Lahaye 1995a, b). In 1997, an important study of Quemener and coworkers (1997) showed the presence of iduronic acid within the ulvan backbone. In general, green algae synthesise the same sulphated polysaccharide. However, the particular amount of each monosaccharide residue or the arrangement of the polysaccharide may vary with different factors, including method of extraction (Love and Percival 1964; Percival and Wold 1963; Siddhanta et al. 2001), geographical distribution or species (Lahaye 1998; Lahaye et al. 1999; Siddhanta et al. 2001), maturity, environmental condition and seasonality (Robic et al. 2009c; Wong and Cheung 2000), resulting in varying ulvan structures (Lahaye and Robic 2007). This variability influences the establishment of an accurate ulvan sugar composition, complicated by the difficulty of determining the presence of different characteristic sugars. This is due to the resistance of aldobiuronic acid to acid hydrolysis and due to the labile nature of iduronic acid, easily degraded by the strong acidic conditions needed to hydrolyse ulvan (Conrad 1980; Lahaye and Robic 2007; McKinnell and Percival 1962a; Ovodov 1975). In order to minimise these effects, innovative methods that combine mild acid hydrolysis with enzymatic degradation have been developed and allow an accurate insight into the ulvan sugar composition and the authentication of the presence of iduronic acid within its backbone (Costa et al. 2012; Quemener et al. 1997).
It is now generally agreed (Lahaye 1998; Lahaye et al. 1999; Lahaye and Ray 1996; Michel and Macfarlane 1996) that the backbone of ulvan is mostly composed of $\alpha$ - and $\beta$ $(1 \rightarrow 4)$-linked sugar residues, namely of $\alpha-1,4$ - and $\alpha-1,2,4-$ linked L-rhamnose 3 -sulphate, with branching at $\mathrm{O}-2$ of rhamnose, $\beta-1,4-$ and terminally linked D-glucuronic acid and $\beta$-1,4-linked D-xylose, partially sulphated on O-2. The major structural units are the $\beta$-D-glucuronosyluronic acid$(1,4)$-L-rhamnose 3 -sulphate dimer $(\beta$-D-GlcpA- $(1 \rightarrow 4)$-LRhap 3-sulphate) and $\alpha$-L-IdopA-( $1 \rightarrow 4)-\alpha$-L-Rhap 3sulphate, also known as ulvanobiuronic acid A and B, respectively (Bobin-Dubigeon et al. 1997a; Lahaye 1998; Lahaye et al. 1997, 1998, 1999; Lahaye and Ray 1996; Quemener et al. 1997). The main difference between these aldobiuronic acids is the presence of glucuronic acid in A, which is replaced by iduronic acid in B (Lahaye et al. 1998). Variations in these main motifs can also be encountered (Lahaye 1998; Lahaye and Robic 2007).

One remarkable feature of ulvan is the presence of rare sugars within its backbone, namely sulphated rhamnose and iduronic acid. Rhamnose is an unusual sugar, usually found in bacteria, plants and being rare in animals, and branching of O-2 of 1,4-linked $\alpha$-L-rhamnose residue was found only on an exopolysaccharide synthesised by the bacterium Arthrobacter sp (Fialho et al. 2008; Lahaye and Ray 1996; Oakes et al. 2010; Popper and Fry 2003; Yapo 2011). The presence of iduronic acid in the ulvan polysaccharidic chain represents another striking characteristic, as this sugar residue has never been identified in algal polysaccharides (Quemener et al. 1997).

\section{Enzymatic degradation}

Degradation of polysaccharides occurs through a sequence of abiotic and/or biological reactions. In order to get a sense on the biodegradation of ulvan, knowledge of its enzymatic cleavage becomes essential. In general, polysaccharide enzymatic degradation is carried by polysaccharide hydrolases or polysaccharide lyases (Tavernier et al. 2008). Polysaccharide lyases, in particular, degrade the polysaccharidic chain by $\beta$-elimination reactions and are usually isolated from bacteria, algae, gastropods and fungi (Linhardt et al. 1986; Tavernier et al. 2008). Despite this knowledge, only a few enzymes with ulvan lyase activity have been identified so far (Table 2). Generally, the discovery and isolation of novel polysaccharide enzymes is based on the need of enzymatic hydrolysis of polysaccharides as a tool for better understanding its structure (Ovodov 1975).

In this regard and, in order to try to elucidate the chemical structure of ulvan and understand the enzymatic degradation of this polysaccharide, an endo-ulvan lyase has been isolated from a marine gram-negative bacterium (Lahaye et al. 
Table 2 Summary of identified enzymes with ulvanolytic activity

\begin{tabular}{llll}
\hline Enzyme & Origin & Activity & References \\
\hline Endo-ulvan lyase & $\begin{array}{c}\text { Marine gram-negative } \\
\text { bacterium } \\
\text { Land snail }\end{array}$ & $\begin{array}{c}\text { Cleavage of }(1 \rightarrow 4) \text { linkage between } \\
\text { rhamnose 3-sulphate and glucuronic acid } \\
\text { Cleavage of }(1 \rightarrow 4) \text { linkage between } \\
\text { rhamnose 3-sulphate and uronic acid } \\
\text { Cleavage of the osidic bond between } \\
\text { ulvanobiuronic acid A and ulvanobiuronic } \\
\text { through } \beta \text {-elimination reaction }\end{array}$ & Lahaye et al (1997); Michaud et al. (2003) \\
Ulvan lyase & Bacteria & $\begin{array}{c}\text { Acetylated and deacetylated glucuronans } \\
\text { in general }\end{array}$ & Delattre et al. (2006) \\
Glucuronan lyase & Filamentous fungi & & \\
\hline
\end{tabular}

1997). These bacteria were selected from slurry rich in decomposing Ulva, and their ulvanolytic activity requires the presence of calcium chloride and has optimum activity at pH 9 (Lahaye et al. 1997). De-polymerisation of ulvan is an endo-molecular process and ulvanobiouronic acid A motif ( $\beta$-D-GlcpA-( $1 \rightarrow 4)$-L-Rhap 3-sulphate) is cleaved resulting in different saccharides with 4-deoxy-L-threo-hex-4-enopyranosyluronic acid at the reducing end (Lahaye et al. 1997; Michaud et al. 2003). The isolation of this lyase permitted new insights into the chemical composition of ulvan.

The same objective was the basis of the work of Quemener and co-workers (1997) who were able to purify a $\beta$ glucuronidase from the snail Helix pomatia and used it to optimise studies on the different sugar composition of ulvans from various sources. In their study, a chemo-enzymatic method was developed to optimise the release of stable monosaccharides after ulvan degradation and $\beta$-glucuronidase was successively used to hydrolyse the resistant disaccharide aldobiuronic acid.

The work of Elboutachfaiti and co-workers (2010) resulted on the successful isolation of an ulvan lyase from a bacterium of the genus Ochrobactrum. This particular enzyme cleaves the osidic bond bridging ulvanobiuronic acid $A$ and ulvanobiuronic $B$, through a $\beta$-elimination reaction (Elboutachfaiti et al. 2010).

Another enzyme with ulvan lyase activity was isolated from a fungus prevalent in soils, Trichoderma sp, and it was identified as a glucuronan lyase. It is dependent on the presence of some ions, including calcium and magnesium, and is sensitive to temperature. Ulvan degradation by this fungal glucuronan lyase originates low molecular weight polysaccharides (Delattre et al. 2006).

Due to the presence of uronic acids within the ulvan backbone, many authors (Lahaye et al. 1999; Leiro et al. 2007; Quemener et al. 1997) have compared it with mammalian glycosaminoglycans, such as chondroitin sulphate. In this sense, and in a biomedical application context, one can infer about the enzymatic susceptibility of ulvan towards naturally occurring mammalian enzymes that degrade this type of molecule into sulphate residues and monosaccharides, such as $\beta$-glucuronidase, hyaluronidase and aryl sulphate (Buermann et al. 1979). Given the evolution of the knowledge of ulvan so far, it should be expected that some of the research focus should now shift towards the understanding of enzymatic degradation of ulvan and the nature of the released products. These studies are especially important when applications such as in medicine, food or pharmaceutics are envisaged. In a particular example, within the context of tissue engineering and regenerative medicine, biodegradability (hydrolytic and/or enzymatic) in physiological conditions is one of the key and crucial properties of biomaterials (Mano et al. 2007).

\section{Properties}

The particular composition and conformation of a given polysaccharide constitute the basis of its physicochemical and biological properties, as well as its particular function on the organism (Jiao et al. 2011; Kreisman et al. 2007; Lazaridou et al. 2004). These unique properties, which distinguish each polysaccharide, define the boundaries of their applicability. Recently, Lahaye and Robic (2007) comprehensively reviewed the available literature on ulvan, with particular emphasis on its structure and properties. Therefore, for the sake of simplicity, this section will focus on some of the most studied properties of ulvan, with special emphasis on its molecular weight distribution, ion bonding, ability to gel and cross-link in the presence of ions, as well as an overview of its biological properties.

\section{Molecular weight}

The molecular weight of a polysaccharide is strongly influenced by various factors, and different molecular weights have been reported for ulvan polysaccharide, which may vary from $1.5 \times 10^{5}$ to $2 \times 10^{6}$ Da (Paradossi et al. 1999, 2002; Siddhanta et al. 2001; Yamamoto 1980). On the other hand, ulvan exhibits an aggregation tendency, which can affect molecular weight determinations (Paradossi et al. 2002). Presence of contaminants, different molecular weight distributions or the occurrence of varying ulvan species with 
variable sugar content and distribution can also influence this property and may explain the polymolecular character of ulvan (Lahaye and Robic 2007).

Nevertheless, it is agreed that ulvan is composed of two major macromolecular populations, identified as a high molecular weight fraction $\left(5 \times 10^{5}\right.$ to $\left.8 \times 10^{5} \mathrm{Da}\right)$ and a medium molecular weight fraction $\left(1.5 \times 10^{5}\right.$ to $\left.2 \times 10^{5} \mathrm{Da}\right)$, being the high molecular weight fraction the most abundant and the one with higher viscosity (Costa et al. 2012; Robic et al. 2008, 2009a).

\section{Selective ion binding}

Green algae are well known for their ability to bind heavy metals, through covalent, electrostatic or redox reactions, removing them from contaminated waters (Bocanegra et al. 2009; Schijf and Ebling 2010; Webster and Gadd 1996). This ability is reported to be associated with the anionic polysaccharide ulvan, present in the cell walls of green algae, which are rich in functional groups with oxygen, including sulphate or hydroxyl groups, as potential metal binding sites (Andrade et al. 2004; Bocanegra et al. 2009; Schijf and Ebling 2010; Webster and Gadd 1996; Webster et al. 1997). In this regard, ulvan demonstrates different affinities towards various ions, such as $\mathrm{Al}>\mathrm{Cu}>\mathrm{Pb}>\mathrm{Zn}>\mathrm{Cd}=\mathrm{Mn}>\mathrm{Sr}>\mathrm{Mg}=\mathrm{Ca}$ (Lahaye and Robic 2007). In the particular case of copper (II) ion, both the uronic acids and sulphate groups of ulvan participate in the fixation of this ion (Paradossi et al. 1999, 2002).

\section{Solution properties and ulvan gelation}

Ulvan is soluble in water and its solubility may be enhanced with temperature (Warrand 2006). However, it cannot markedly thicken aqueous solutions and forms weak gels in deionized water, susceptible to $\mathrm{pH}$ and ions, with low intrinsic viscosity (Lahaye and Axelos 1993; Lahaye and Jegou 1993; Robic et al. 2009a).

When in aqueous solution, ulvan tends to arrange in a bead-like structure, partially linked by filaments (Robic et al. 2009a). This peculiar behaviour is explained by a localised hydrophobic character present within this charged polysaccharide, mostly related with the presence of hydrophobic methyl groups of rhamnose (Robic et al. 2009a). As water can be considered as a poor solvent for this polysaccharide, this may explain the low viscosities observed for aqueous ulvan solutions (Robic et al. 2009a, b). Decrease of pH towards acidic moieties forces ulvan beads to disperse into an isolated form (Robic et al. 2009a). Increasing solution pH promotes ionic interactions between carbonyl and sulphate groups, resulting in aggregation of ulvan beads (Robic et al. 2009a). The same behaviour is observed in saline ulvan solutions or in the presence of boron or copper, where polysaccharide self-associations are enhanced (Lahaye 2001; Paradossi et al. 1999, 2002; Robic et al. 2009a).

In general, ulvan gels are formed in the presence of boric acid and divalent cations, or copper, at slightly alkaline moieties (Lahaye 2001; Lahaye and Axelos 1993; Lahaye et al. 1998; Lahaye and Robic 2007; Paradossi et al. 1999; Robic et al. 2009a; Toskas et al. 2011). The important study of Lahaye and Axelos (1993) determined the gelation kinetics of ulvan in the presence of both boron and calcium ions, which led to the conclusion that gelation of this polysaccharide is time- and $\mathrm{pH}-d e p e n d e n t$. In an appropriate ionic milieu, this polysaccharide forms a gel and the reaction mechanism is thought to involve the cross-linking between ulvan and boron, mediated by calcium ions (Lahaye and Axelos 1993; Lahaye et al. 1998; Toskas et al. 2011). A mechanism of gelation of ulvan in the presence of boron and calcium was proposed to require the presence of free cishydroxyls, involving rhamnose or uronic acids (Lahaye and Axelos 1993). However, further research on this matter has revealed that this scenario does not truly represent the gelation reaction mechanism. The high sulphation degree of ulvan, mostly localised in rhamnose, may make crosslinking difficult, which suggests that this particular sugar residue may not be involved in the gel formation through boron interactions (Lahaye et al. 1998). On the other hand, no borate complex was detected, neither involving glucuronic acid nor iduronic acid (Lahaye et al. 1998). Therefore, the particular gelation mechanism of ulvan in the presence of boron is yet to be determined and may involve minor sugars also present within the ulvan backbone (Lahaye et al. 1998).

In agreement with the involvement of ulvan in the ability of green algae to bind metal ions, Paradossi and co-workers (1999) found an affinity of this polysaccharide towards copper (II), and Lahaye and co-workers (as cited in Lahaye and Robic 2007) were able to induce gelation of ulvan in the presence of copper, zinc, magnesium and calcium.

The peculiar gelation behaviour of ulvan may result from the aggregation of ulvan bead-like structures through hydrophilic moieties present within this polysaccharide (Robic et al. 2009a). Nevertheless, the viscosity of polysaccharide solutions and gel-forming ability are highly dependent on the chemical composition of the polysaccharide itself (Robic et al. 2009c). In the particular case of ulvan, the high uronic acid content seems to affect the viscosity of ulvan solutions and the ability to form gel (Siddhanta et al. 2001). In fact, gel formation depends on intra- and inter-molecular crosslinks, which are hampered by highly negative groups, including carboxylic acids (like uronic acids), sulphate groups and/or methyl groups (in rhamnose) (Lahaye 2001). An example of the striking effect of sulphation degree on the gelation ability of a polysaccharide is carrageenan. The three main types of carrageenan are kappa, iota and lambda and 
the main difference between these polysaccharides is their increasing sulphate content (Williams 2009). Both kappa and iota carrageenan adopt an ordered double helical structure and form thermoreversible gels through coil-helix conformational transition (Williams 2009). However, the higher sulphation degree of lambda carrageenan impedes helix formation and consequently gel formation, possibly through steric hindrance or electrostatic repulsion (Williams 2009). Despite the results and hypotheses gathered concerning the gelation of ulvan, this is still an open field of research and the mechanisms of gelation are yet to be fully understood.

\section{Biological properties}

Marine algae constitute a rich and largely available source of sulphated polysaccharides with peculiar structures associated with different biological activities (Jiao et al. 2011; Wijesekara et al. 2011; Yang and Zhang 2009). These have been the focus of intense research and different structurefunction studies reveal that these are many times correlated with the degree of sulphation of these polysaccharides (Jiao et al. 2011; Wijesekara et al. 2011).

In general, polysaccharides are regarded as non-cytotoxic polymers of natural origin (Jani et al. 2009). Ulvan, in particular, already has been studied and its toxicological effects revealed (Alves et al., unpublished). It was characterised in terms of its biological performance, evaluated by means of in vitro cytotoxicity assays, and it has been demonstrated that this polysaccharide is cytocompatible and is considered non-toxic in the range of concentrations studied (Alves et al., unpublished). Furthermore, its cellular effect was similar to hyaluronic acid, used as a control in their studies (Alves et al., unpublished). However, a change in the toxicity of this polysaccharide towards colonic epithelial cells was detected for modified ulvans, with low content or reduced uronic acids or de-sulphated ulvans (Kaeffer et al. 1999).

Ulvan has been described as a heparinoid agent, meaning that it possesses biological activity similar to that of heparin as a potent anti-coagulant (El-Baky et al. 2009; Harada and Maeda 1998; Mao et al. 2006). It also has been found that this polysaccharide is a potent anti-viral agent, particularly against influenza virus, both human and avian, and Herpes Simplex Virus 1 (El-Baky et al. 2009; Kaeffer et al. 1999). Furthermore, it has anti-hyperlipidemic properties, and both ulvan and its low molecular weight oligosaccharides demonstrate an effect on lipid metabolism, limiting hyperlipidemy (Bocanegra et al. 2009; Pengzhan et al. 2003a, b; Sathivel et al. 2008). Its anti-peroxidative and antihyperlipidemic properties have shown to exert a protective effect over the liver of rats exposed to a hepatitis-inducing toxin (Devaki et al. 2009; Sathivel et al. 2008). Anti-oxidant activity was additionally recognised in ulvan, namely scavenging activity towards superoxide and hydroxyl radicals, metal chelating activity and reducing power (Costa et al. 2010; El-Baky et al. 2009; Kuda and Ikemori 2009; Qi et al. 2005a, b, 2010). This trait is influenced by the molecular weight of the polysaccharide and its oligosaccharides, as well as by the sulphate content of ulvan and its derivatives (Qi et al. 2005a, b, 2010). Chemical modifications of the natural polysaccharide, such as acetylation and benzoylation described by Qi et al $(2006,2010)$ may enhance this ability. Another important feature of ulvan is its immunostimulating ability, comparable to other algal polysaccharides (Castro et al. 2004, 2006; Leiro et al. 2007). It has been reported to induce respiratory burst in flatfish and mammalian phagocytes (Castro et al. 2004, 2006; Leiro et al. 2007; van Rooijen and Sanders 1997). Phagocyte activation is a key process in the host defence against microorganisms, and it is mostly related with the anti-oxidant properties already recognised in this polysaccharide (Castro et al. 2004, 2006; De la Fuente et al. 2011; Leiro et al. 2007). This activity is strongly influenced by the presence of sulphate groups as well as by exposure time and concentration and may occur through interaction of the polysaccharide with cell surface receptors (Castro et al. 2004, 2006; De la Fuente et al. 2011; Leiro et al. 2007). Ulvan can also mediate intestinal epithelial growth and take part on the repair of wounds by stabilising and promoting binding of relevant growth factors to intestinal cells (Warrand 2006). Ulvan has demonstrated anti-proliferative activities against human cancer cells, in a dose-dependent manner, particularly for breast adenocarcinoma cells (El-Baky et al. 2009). This may be correlated with its sulphate content and richness in uronic acids (ElBaky et al. 2009).

As mentioned before, many of the biological properties of ulvan are strongly influenced by its degree of sulphation. However, they can also be related to the ubiquitous presence of rhamnose within the backbone of this algal polysaccharide (Andrès et al. 2006). In general, rhamnose-rich polysaccharides possess anti-inflammatory properties, reduce bacterial adhesion to the skin, protect skin from UVinduced and age-related damage and stimulate cell proliferation and collagen biosynthesis (Andrès et al. 2006; Faury et al. 2011). In fact, skin keratinocytes and fibroblasts possess lectins that recognise rhamnose moieties present within a polysaccharide (Andrès et al. 2006; Faury et al. 2011). These peculiarities of this type of polysaccharides have generated a unique interest for the treatment of skin pathologies, particularly the ones related with age and its effects (Andrès et al. 2006; Faury et al. 2011).

Polysaccharides of marine origin are often associated with important biological activities, which are affected by different factors, including molecular weight, chemical composition and chain conformation (Yang and Zhang 2009). Ulvan is no exception and, as it happens with many 
other polysaccharides, these properties justify the applicational interest on this green algal polysaccharide.

\section{Applications}

The interest in marine algae, as sources of unique polysaccharides with novel structures and interesting biological activities for innovative potential applications, is increasing. These include food, pharmaceutical and medical industries as well as microbiologican and biotechnological applications (Bocanegra et al. 2009). However, few of the world's available algae species are used commercially. Among the three main divisions of macroalgae (Chlorophyta, Phaeophyta and Rhodophyta), green algae remain largely unexploited in these areas. Gosselin and co-workers (1964) noticed, in the early 1960s, the discrepancy in knowledge of green algae polysaccharides when compared to brown and red algae. Almost half a century later, this is still a quite valid consideration. Although knowledge has evolved, green algae are still a rather underexploited biomass. Their polysaccharides remain in the field of possibilities, against, for instance alginate and carrageenan or agar. These are well established and worldwide-accepted polysaccharides for diverse applications, ranging from the food industry to biomedical field (Bocanegra et al. 2009; Ertesvag and Valla 1998; Jensen 1993; Renn 1984).

Ulvan from different sources is demonstrating ubiquitous potential to be successfully used in various applications. In this section, the applicability of ulvan as a polysaccharide will be discussed, although one should bear in mind that ulvan oligosaccharides also demonstrate interesting properties that may justify more research and development of future applications, particularly those related to its biological properties (Courtois 2009; Pengzhan et al. 2003a; Qi et al. 2005b; Zhang et al. 2008).

Active agent for pharmaceutical applications

A review of algae applicability focused on pharmaceutical and medical applications was written by Albertus Smit (2004), who notes the ecological significance and potential of algae: "Phycologists may be surprised to discover how frequently seaweed natural products are discussed in medicine".

In ancient times, green algae were used to treat different pathologies, including hyperlipidemia and urinary diseases (Pengzhan et al. 2003a). Nowadays the medicinal interest in green algae is centred in its polysaccharidic part, particularly ulvan, to be used as a therapeutic active agent.

The presence of glucuronic and iduronic acids makes ulvan a very special polysaccharide. This fact gains importance as we think of this polysaccharide for pharmaceutical and biomedical applications. Both these sugar residues are important constituents of mammalian glycosaminoglycans, including heparin and chondroitin sulphates (Lahaye et al. 1999; Leiro et al. 2007; Quemener et al. 1997). Another remarkable property of ulvan is its sulphation degree. Sulphate groups have long been associated with different biological activities (Jiao et al. 2011). In fact, sulphated polysaccharides are abundant within animal cells and participate in cell recognition, adhesion or regulation of receptor functions (Leiro et al. 2007; Pengzhan et al. 2003b).

The use of ulvan as a strategic alternative to various synthetic or animal bioactive agents would take advantage of its algal origin, together with high availability and low expected production costs, low cytotoxicity and broad spectrum of biological activities. It could be applied as an antiviral agent (El-Baky et al. 2009; Kaeffer et al. 1999), antioxidant (Costa et al. 2010; Kuda and Ikemori 2009; Qi et al. 2005a, b, 2006, 2010), as an anti-coagulant alternative to heparin (El-Baky et al. 2009; Harada and Maeda 1998; Mao et al. 2006), anti-hyperlipidemic (Bocanegra et al. 2009; Devaki et al. 2009; Pengzhan et al. 2003a, b; Sathivel et al. 2008) or of its anti-proliferative activity towards cancer cells (El-Baky et al. 2009), or for therapy for diseases where the immune system is impaired (Castro et al. 2004, 2006; Leiro et al. 2007). Furthermore, due to its similarity with mammalian glycosaminoglycans, it could be exploited as a pharmaceutical where the delivery of glycosaminoglycans is needed, such as for the treatment of musculoskeletal disorders (Ghisalberti 2010; Larraz et al. 2007). On the other hand, rhamnose moieties ubiquitous in the ulvan backbone, as mentioned above, may be the basis for its use for the treatment of skin pathologies, particularly the ones related with age and its effects (Andrès et al. 2006; Faury et al. 2011). Massarelli et al (2007) have studied the interaction of ulvan with hepatocyte lectins and found that the presence of xylose within the backbone of this polysaccharide mediates the interaction with these membrane receptors. As ulvan is readily recognised by hepatocyte membrane receptors, it could be used as a biomaterial for diagnostic or therapeutic purposes (Massarelli et al. 2007). Moreover, and taking advantage of the ability of ulvan to complex with metal ions (Lahaye and Robic 2007), it can find applications where the removal of these ions from the body is required or to warrant the presence of ions when they are needed. For example, it can be used in the therapy for metal poisoning or even be used as part of drugs relevant for targeted radioactive treatment of tumours, as already proposed for carrageenan (Khotimchenko et al. 2010). Ulvan's biological activities and possible applicative scenario are summarised in Table 3.

Medical devices

Side by side with its biological properties and potential pharmaceutical relevance, one can think of ulvan for 
Table 3 Summary of relevant biological activities associated with ulvan and its potential strategic application in a pharmaceutical context, according to diverse studies reported in the literature

\begin{tabular}{|c|c|c|}
\hline Biological activity & Strategic possible applications & References \\
\hline Anti-viral & $\begin{array}{l}\text { Treatment of viral infections, } \\
\text { particularly influenza and HSV-1 }\end{array}$ & $\begin{array}{l}\text { El-Baky et al.(2009); Kaeffer et al. (1999); } \\
\text { Muto et al. (1992) }\end{array}$ \\
\hline Anti-oxidant & $\begin{array}{l}\text { Prevention of oxidative stress and } \\
\text { be used as a protective drug for } \\
\text { several pathologies, including } \\
\text { age-related or cancer }\end{array}$ & $\begin{array}{l}\text { Costa et al. (2010); Kuda and Ikemori (2009); } \\
\text { Qi et al. (2005a, b, 2006, 2010); } \\
\text { Daniels (2004a, b) }\end{array}$ \\
\hline Anti-coagulant & Surrogate of heparin & $\begin{array}{l}\text { El-Baky et al. (2009); Harada and Maeda (1998); } \\
\text { Mao et al. (2006); Maeda et al. (1992); } \\
\text { Daniels (2004a, b) }\end{array}$ \\
\hline Anti-hyperlipidemic & Regulation of lipid metabolism & $\begin{array}{l}\text { Bocanegra et al. (2009); Devaki et al. (2009); } \\
\text { Pengzhan et al. (2003a, b); Sathivel et al. (2008); } \\
\text { Daniels (2004a, b) }\end{array}$ \\
\hline Immunostimulating & $\begin{array}{l}\text { Therapy for diseases where the } \\
\text { immune system is impaired }\end{array}$ & $\begin{array}{l}\text { Castro et al. (2004, 2006); Leiro et al. (2007); } \\
\text { Daniels (2004a) }\end{array}$ \\
\hline Anti-proliferative towards cancer cells & $\begin{array}{l}\text { Agent for inhibition of cancer } \\
\text { cells proliferation }\end{array}$ & El-Baky et al. (2009) \\
\hline
\end{tabular}

biomedical applications, in particular for the production of medical devices. In this regard, the technological development of ulvan is still in the field of possibilities and mainly focused on its applicability as a biomaterial for tissue engineering and regenerative medicine. Within the context of tissue engineering and regenerative medicine, the main objective is to guide cells into forming a functional living tissue (Mano et al. 2007). A common strategy involves the use of biodegradable scaffolds that provide structure and support cell adhesion, differentiation and proliferation (Mano et al. 2007). Depending on the target tissue, one is trying to repair, regenerate or substitute polysaccharide-based systems can assume different forms, with different functionalities, ranging from nano-particulate structures to complex 3-D scaffolds, passing through smart systems. Materials of natural origin present the additional advantage of possessing a variety of distinctive biochemical cues that may enhance and define their applicability in a biomedical context (Barbosa et al. 2005; Mano et al. 2007; Oliveira and Reis 2011). The promise that tissue engineering and regenerative medicine holds is becoming more realistic as significant milestones are achieved, particularly by the approval and commercialization of different developed systems based on natural polymers. Examples of commercial medical devices include CollaGuide $^{\mathrm{TM}}$ and Novocart 3D Autologous Chondrocyte Transplantation, based on collagen, which are used for guided tissue regeneration and cartilage engineering, respectively, and alginate and chitosan wound dressings (Tegagen ${ }^{\mathrm{TM}}$ Alginate Dressing, Sorbsan ${ }^{\circledR}$ and ChitoFlex $\left.{ }^{\circledR}\right)$.

In this area, as it happens in a general applicative overview, when one thinks about polysaccharides of marine origin, both research and market are generally based on chitin and chitosan (Correlo et al. 2010; Cruz et al. 2008;
Grenha et al. 2009; Santos et al. 2007; Silva et al. 2011), carrageenan (Grenha et al. 2009; Pereira et al. 2009; Popa et al. 2011; Santo et al. 2009) and alginate (Bernhardt et al. 2009; Popa et al. 2011) (Costa-Pinto et al. 2011; d' Ayala et al. 2008; Mano et al. 2007; Oliveira and Reis 2011).

The use of ulvan as a medical device, for applications such as tissue engineering and regenerative medicine, is at its early stage, particularly on what concerns polysaccharide modification and processing and biomaterial design. Nevertheless, diverse ulvan structures for different end applications have been so far developed and are already reported in the literature. These include nano-fibres (Toskas et al. 2011), membranes (Alves et al. 2012b), particles (Alves et al. 2012a), hydrogels (Morelli and Chiellini 2010) and 3D porous structures (Alves et al., unpublished). An overview of these structures is presented in Table 4. Proposed applications include drug delivery, wound dressing or bone tissue engineering (Alves et al. 2012a, b; Morelli and Chiellini 2010; Toskas et al. 2011).

\section{Personal care products}

The array of personal care products is quite broad and there is a tendency towards the use of products of natural origin, including algae extracts (Barsanti and Gualtieri 2006; Kim et al. 2008; Weisberg and Baumann 2009). The use of ulvan in this particular industry is poorly described, being mostly limited to patents that illustrate and claim the use of ulvan or a water extract from green algae, in this field (Blin 2007; Briand 1991; Demais et al. 2006). However, it is easy to envision the potential applicability of this polysaccharide in personal care products, especially if one considers its described biological properties. First of all, ulvan presents 
Table 4 Structures based on ulvan developed for biomedical applications, including tissue engineering and regenerative medicine

\begin{tabular}{lll}
\hline Structure & Processing methodology & References \\
\hline Nano-fibres & $\begin{array}{c}\text { Electro-spinning of a blend solution } \\
\text { based on ulvan and poly(vinyl alcohol) } \\
\text { Modification of ulvan by chemical } \\
\text { cross-linking with butanediol diglycidyl } \\
\text { ether followed by solvent casting } \\
\text { Extrusion-dripping method to form ulvan } \\
\text { particles by electrostatic interaction } \\
\text { Particles }\end{array}$ & Toskas et al. (2011) \\
Hydrogelycation (chitosan) & Alves et al. (2012a) \\
3-D porous structures & $\begin{array}{l}\text { Modification of ulvan with methacryloyl } \\
\text { groups followed by photopolymerization } \\
\text { Freeze-drying of a solution prepared with } \\
\text { ulvan cross-linked with butanediol } \\
\text { diglycidyl ether }\end{array}$ & Mlves et al. (unpublished) \\
\hline
\end{tabular}

similarities with glycosaminoglycans, like chondroitin and dermatan sulphate, ubiquitous in skin tissue (Baumann and Saghari 2009; Lahaye et al. 1999; Leiro et al. 2007; Quemener et al. 1997). Furthermore, being a polysaccharide rich in rhamnose moieties, it may induce cell proliferation and collagen biosynthesis (Andrès et al. 2006; Faury et al. 2011). On the other hand, it has proven anti-oxidant properties and high hydration ability (Bocanegra et al. 2009; Costa et al. 2010; Kuda and Ikemori 2009; Qi et al. 2005a, b, 2006, 2010). In fact, the presence of glucuronic acid within the ulvan chain confers moisturising properties to this polysaccharide, important in protecting skin and preventing damage by exposure to dry environments (Kim et al. 2008). These particularities reinforce ulvan's value for cosmetic applications.

\section{Food industry}

Green algae have been present in the diet of humans since ancient times and are considered as food and an alternative and rich source of vegetables (Bocanegra et al. 2009; Castro-Gonzalez et al. 1996; Jensen 1993; Wong and Cheung 2000). They are traditionally consumed in Asia and are also approved for consumption in Europe, namely in France (Bocanegra et al. 2009; Castro-Gonzalez et al. 1996; Lahaye et al. 1994; Pengzhan et al. 2003a; Wong and Cheung 2000). In fact, the consumption of Ulva poses no threat to human health (Andrieux et al. 1998). These algae are rich in soluble and insoluble dietary fibres and important minerals, as well as vitamins, polysaccharides, chlorophyll and protein, and low lipid content (Bocanegra et al. 2009; Ortiz et al. 2006; Pengzhan et al. 2003a; Wong and Cheung 2000). In fact, nutritional interest in algae resides on their wealth on vitamins, oligoelements, minerals and dietary fibres (Lahaye and Jegou 1993; Ortiz et al. 2006). On the other hand, algae are considered as low-energy food due to their low lipid content and the fact that their carbohydrates are resistant to digestion and fermentation (Andrieux et al. 1998; Bobin-Dubigeon et al. 1997a; Bocanegra et al. 2009;
Lahaye 1991; Michel and Macfarlane 1996). Besides consumption of algae, one can make use of their constituents for food-related applications. The majority of algal polysaccharides, including ulvan, are resistant to endogenous human digestive enzymes (Lahaye 1991; Michel and Macfarlane 1996; Wood 1974), and for this reason, they can be considered as good sources of dietary fibres (Bocanegra et al. 2009; Lahaye 1991). These fibres are present in algae in larger quantities compared to land plants and can be divided into water soluble and insoluble fibres (Andrieux et al. 1998; Lahaye 1991; Lahaye and Jegou 1993; Wong and Cheung 2000). Ulvan is recognised as a soluble dietary fibre (Andrieux et al. 1998; Bobin-Dubigeon et al. 1997a; Lahaye 1991), and it is resistant to hydrolysis by digestive enzymes. Its digestive fate has been proposed to be mostly related with de-polimerization and fermentation by the large intestinal bacteria (Michel and Macfarlane 1996). However, ulvan demonstrates low fermentability and is poorly degraded by faecal bacteria (Andrieux et al. 1998; Bobin-Dubigeon et al. 1997a). This trait is strongly influenced by its characteristic chemical structure, with little influence of sulphate groups on the resistance of this polysaccharide to bacterial degradation (Bobin-Dubigeon et al. 1997a). In fact, its resistance to degradation is maintained after the removal of sulphate groups or oxidation of uronic acid and can be associated with the absence of ulvan-specific de-polymerases in colonic microflora (Durand et al. 1997; Ray and Lahaye 1995a). This is in accordance with the fact that different bacteria present in human flora do not use ulvan as a source of carbohydrates (Rochet and Bernalier 1997). Even though ulvan is poorly fermented, it induces positive effects on the metabolism of colonic microflora, including regulation of the activity of the enzymes $\beta$-glucuronidase and $\beta$-glucosidase (Andrieux et al. 1998) and induction of intestinal mucin secretion (Barcelo et al. 2000). Interestingly, it appears that sulphate groups are not the main responsible for some of these effects (Barcelo et al. 2000; Bobin-Dubigeon et al. 1997a; Ray and Lahaye 1995a). 
Dietary fibres possess many interesting properties which render them well-established additives for food industry applications, as thickeners, stabilisers, emulsifiers or as bulking or gelling agents (Bocanegra et al. 2009; Wood 1974). In general, algae dietary fibres, including ulvan, have remarkable hydration ability, form solutions with different viscosities, and are able to interact with relevant biological molecules, including cholesterol, and provide bulk to faeces (Bocanegra et al. 2009). Furthermore, ulvan can be used in this particular industrial niche for its anti-oxidant properties, preventing food deterioration (Wijesekara et al. 2011).

Other applications

Besides pharmaceutical, biomedical or food-related applications, ulvan has been studied and can be applied in many other areas, ranging from agriculture to more technical usages.

Plant pathogens pose an important threat to agricultural production. In this regard, elicitors of plant defence mechanisms represent a powerful alternative to pesticides (MejíaTeniente et al. 2010). A good elicitor triggers defence responses and ensures protection to different diseases without disturbing the organism's primary metabolism (Cluzet et al. 2004).

Ulvan has been demonstrated to activate signalling pathways of intracellular plant defence and exerted a protective effect against plant diseases, proving its potential applicability as an environmental friendly plant pathogens' control (Araújo et al. 2008; Briand et al. 2005; Cluzet et al. 2004; Freitas and
Stadnik 2012; Jaulneau et al. 2010; Montealegre et al. 2010; Paulert et al. 2009). In fact, pre-treatment of plants with ulvan induces plant resistance and reduces the impact and severity of fungal diseases; however and despite this effect on the plant itself, ulvan does not impede mycelia growth (Araújo et al. 2008; Montealegre et al. 2010; Paulert et al. 2009). This activity may be associated with its sulphate content as well as with the presence of rhamnose and uronic acid in its composition, acting through the jasmonic acid pathway (Jaulneau et al. 2010). In a more technical application of this polysaccharide, Castro et al. (2008) have used ulvan to purify a neutrophil fish mieloperoxidase (Castro et al. 2008). This particular application of ulvan is based on its anionic nature and on the fact that this polysaccharide resembles some glycosaminoglycans, enabling the binding of the enzyme via electrostatic interactions and its isolation and purification by affinity chromatography (Castro et al. 2008). Furthermore, being largely composed of rhamnose, ulvan can be considered a good and cheap raw material to obtain this valuable monosaccharide (Takemura et al. 1986).

\section{Relevant patents}

The increasing demand for novel polymers side by side with the sustainable exploitation of natural resources is forcing the focus of research towards polymers of natural origin, particularly from marine origin. This mining of the ocean's resources is the basis of different emergent industries based

Table 5 Summary of patents related to ulvan or its derivatives

\begin{tabular}{|c|c|c|c|}
\hline Product based on/including & Application & Priority & Patent number \\
\hline Water extract from green algae & Source of L-rhamnose & 1986 & US 4758283 (Takemura et al. 1986) \\
\hline Water extract from green algae & Active agent for anti-viral drugs & 1987 & US 5089481 (Muto et al. 1992) \\
\hline Water extract from green algae & $\begin{array}{l}\text { General use for cosmetic, pharmaceutical, } \\
\text { food or agricultural applications }\end{array}$ & 1989 & WO 91/07946 (Briand 1991) \\
\hline Water extract from green algae & Agent with anti-coagulant activity & 1990 & EP 0475383 (Maeda et al. 1992) \\
\hline Water extract from green algae & $\begin{array}{l}\text { Therapeutic agent for treatment of } \\
\text { cardiovascular pathologies }\end{array}$ & 2004 & US 2004/0170645 (Daniels 2004a) \\
\hline Ulvan & $\begin{array}{l}\text { Elicitor of plant defence mechanisms } \\
\text { for agricultural applications }\end{array}$ & 2004 & WO 2005/094588 (Briand et al. 2005) \\
\hline Ulvan & $\begin{array}{l}\text { Use of ulvan as interspacing component to } \\
\text { prepare an interspersed clay for cosmetic, } \\
\text { pharmaceutical, food or packaging applications }\end{array}$ & 2004 & WO 2006/030075 (Demais et al. 2006) \\
\hline Water extract from green algae & $\begin{array}{l}\text { Pharmacological agent for therapy for } \\
\text { neuropathies associated with diabetes } \\
\text { and preservation of renal function } \\
\text { and vasculopathies }\end{array}$ & 2004 & WO 2004/103280 (Daniels 2004b) \\
\hline Ulvan & $\begin{array}{l}\text { Modification of ulvan and use of the } \\
\text { resulting product as a surfactant }\end{array}$ & 2005 & WO 2007/045795 (Ranson et al. 2007) \\
\hline Ulvan & $\begin{array}{l}\text { Cosmetic composition, making-up } \\
\text { or caring for skin and lips }\end{array}$ & 2005 & WO 2007/007294 (Blin 2007) \\
\hline Ulvan & $\begin{array}{l}\text { Cleansing and detoxifying agent composed } \\
\text { of alginate and ulvan }\end{array}$ & 2007 & US 2009/0060942 (O’Mara and O'Mara 2009) \\
\hline Water extract from green algae & $\begin{array}{l}\text { Agent for topical application for the } \\
\text { treatment of hot flashes }\end{array}$ & 2008 & WO 2009/142745 (France 2009) \\
\hline
\end{tabular}


on the unique properties of molecules of marine origin. Examples of successful enterprises include Porifarma B. V. (The Netherlands), BioTechMarine (France) and Seanergy (Faroe Islands), among others. In the particular case of ulvan, the interest in this polysaccharide is being revealed by the increasing number of patents focused on the different possibilities of application development based on this polysaccharide, ranging from cosmetics, food, agricultural, pharmaceutical to more technical applications. A resume of this intellectual property is disclosed in Table 5.

\section{Outlook and perspectives}

The interest on molecules of marine origin is not recent and has always attracted attention of visionary entrepreneurs for innovative industrial applications. Within this context and given the evolution and advances of polysaccharides of marine origin of different sources, it is surprising to see the limited evolution of green algae polysaccharides. This is particularly striking if one considers that the study of green algae polysaccharides is being documented since the beginning of the twentieth century. A possible justification for this impaired development may reside on the peculiar and complex structure of ulvan, only completely unravelled in 1997 with the definite confirmation of the presence of iduronic acid within the ulvan backbone (Quemener et al. 1997). It was only in 2009 that Robic and co-workers shed some light on the abnormal behaviour of this polysaccharide in aqueous solutions (Robic et al. 2009a). This knowledge has strong impact on the future application development of this polysaccharide. Since the early 1990s, research focused on ulvan has been increasing, with a particular focus on its structure and composition, as well as on its properties. Interest on the application development is far more recent. However, the potential of this green algae polysaccharide is such that intellectual property is being reported since mid1980 s. When compared with other polysaccharides originated from red and brown algae, ulvan may be considered as a late bloomer. However, the limits of its potential applicability are being drawn, and the knowledge generated during the past few years will drive research a step further towards the application development of this green algae polysaccharide.

\section{Final remarks}

As the fundamental knowledge on ulvan increases, research on this polysaccharide tends to shift towards applied science. However, this evolution is naturally impaired by a lack of a standardised commercial form of this polysaccharide. In this regard, the design of a novel and effective extraction procedure, focused towards targeted applications, becomes crucial. This certainly will open the way to the possibility of scaling up. This is an important consideration, if continuous research on ulvan is intended.

The literature is rich on reports highlighting the peculiar nature and diverse properties associated to this polysaccharide. In fact, a large portion of research efforts are focused on the study of ulvan chemistry and properties. This knowledge constitutes the fundamental basis that supports applied studies in an attempt to position ulvan as a valid alternative to other polymers, in diverse areas of knowledge. In this sense, this polysaccharide can find niches of application in areas like the pharmaceutical industry or the biomedical arena, for instance as a bioactive compound or as a medical device, or find applicability in the personal care products' market, or in the food industry or even in agriculture. However, it is the authors' belief that a practical understanding on ulvan's applicability is still a rather open field of research. This is of course enhanced by the particular demands of each niche of application. For example, if one considers ulvan in a biomedical context to be used as a medical device for regenerative purposes, considerable research endeavour is still needed to accomplish clinical relevance based on ulvan. In this particular context, research strategies may be focused, for instance, on polysaccharide modification, processing and material design and/or material-cell interactivity in order to achieve successful development.

Although the task of translating fundamental research on ulvan into practical achievements appears substantial, this polysaccharide holds great potential and versatility. Taking advantage of the knowledge, gathered research can now be driven towards practical applications of ulvan in an attempt to decrease the distance between scientific understanding and industrial awareness. The promise of success is feasible and for now, one can only say "alea jacta est".

Acknowledgments Anabela Alves is grateful for financial support from the Fundação para a Ciência e Tecnologia through the SFRH/ BD/39359/2007 grant. This work was partially supported by the project IBEROMARE approved by the Operational Programme for Crossborder Cooperation: Spain-Portugal, 2007-2013 (POCTEP), with funding contribution through the European Regional Development Fund (ERDF co-funding) and POCTEP.

\section{References}

Abdel-Fattah AF, Edrees M (1972) A study on the polysaccharide content of Ulva lactuca L. Qual Plant Mater Veg 22:15-22

Alves A, Caridade SG, Mano JF, Sousa RA, Reis RL (2010) Extraction and physico-chemical characterization of a versatile biodegradable polysaccharide obtained from green algae. Carbohyd Res 345:2194-2200

Alves A, Duarte ARC, Mano JF, Sousa RA, Reis RL (2012a) PDLLA enriched with ulvan particles as a novel 3D porous scaffold targeted for bone engineering. J Supercrit Fluid 65:32-38 
Alves A, Pinho ED, Neves NM, Sousa RA, Reis RL (2012b) Processing ulvan into 2D structures: cross-linked ulvan membranes as new biomaterials for drug delivery applications. Int $\mathrm{J}$ Pharm 426:76-81

Andrade LR, Salgado LT, Farina M, Pereira MS, Mourao PAS, Amado Filho GM (2004) Ultrastructure of acidic polysaccharides from the cell walls of brown algae. J Struct Biol 145:216-225

Andrès E, Molinari J, Péterszegi G, Mariko B, Ruszova E, Velebny V, Faury G, Robert L (2006) Pharmacological properties of rhamnose-rich polysaccharides, potential interest in agedependent alterations of connectives tissues. Pathol Biol $54: 420-425$

Andrieux C, Hibert A, Houari A-M, Bensaada M, Popot F, Szylit O (1998) Ulva lactuca is poorly fermented but alters bacterial metabolism in rats inoculated with human faecal flora from methane and non-methane producers. J Sci Food Agr 77:25-30

Araújo L, Stadnik MJ, Borsato LC, Valdebenito-Sanhueza RM (2008) Potassium phosphite and ulvan in the control of 'Gala' leaf spot on apple. Trop Plant Pathol 33:148-152

Barbosa MA, Granja PL, Barrias CC, Amaral IF (2005) Polysaccharides as scaffolds for bone regeneration. ITBM-RBM 26(3):212217

Barcelo A, Claustre J, Moro F, Chayvialle JA, Cuber JC, Plaisancie P (2000) Mucin secretion is modulated by luminal factors in the isolated vascularly perfused rat colon. Gut 46:218-224

Barsanti L, Gualtieri P (2006) Algae-anatomy, biochemistry and biotechnology. Taylor \& Francis Group, New York

Baumann L, Saghari S (2009) Basic science of the dermis. In: Baumann L, Saghari S, Weisberg E (eds) Cosmetic dermatology, principles and practice, 2nd edn. McGraw-Hill, New York, pp 8-13

Béress A, Wassermann O, Bruhn T, Béress L, Kraiselburd EN, Gonzalez LV, de Motta GE, Chavez PI (1993) A new procedure for the isolation of anti-HIV compounds (polysaccharides and polyphenols) from the marine alga Fucus vesiculosus. J Nat Prod 56:478-488

Bernhardt A, Despang F, Lode A, Demmler A, Hanke T, Gelinsky M (2009) Proliferation and osteogenic differentiation of human bone marrow stromal cells on alginate-gelatine-hydroxyapatite scaffolds with anisotropic pore structure. J Tissue Eng Regen M 3 (1):54-62

Blin X (2007) Film of cosmetic product. FR Patent WO 2007/007294 (18 January 2007)

Bobin-Dubigeon C, Lahaye M, Barry J-L (1997a) Human colonic bacterial degradability of dietary fibres from sea-lettuce (Ulva sp.). J Sci Food Agr 73:149-159

Bobin-Dubigeon C, Lahaye M, Guillon F, Barry J-L, Gallant DJ (1997b) Factors limiting the biodegradation of Ulva sp. cell-wall polysaccharides. J Sci Food Agr 75:341-351

Bocanegra A, Bastida S, Benedi J, Rodenas S, Sanchez-Muniz FJ (2009) Characteristics and nutritional and cardiovascular-health properties of seaweeds. J Med Food 12:236-258

Brading JWE, Georg-Plant MMT, Hardy DM (1954) The polysaccharide from the alga Ulva lactuca-purification, hydrolysis, and methylation of the polysaccharide. J Chem Soc:319-324

Briand X (1991) Utilisation of extracts of algae for the preparation of pharmaceutical, cosmetic, food or agricultural compositions. PCT Patent WO 91/07946 (13 June 1991)

Briand X, Cluzet S, Esquerre-Tugaye M-T, Salamagne S, Dumas B (2005) Use of ulvans as activators of plant defence and resistance reactions against biotic and abiotic stresses. PCT Patent WO 2005/094588 (13 October 2005)

Bruhn A, Dahl J, Nielsen HB, Nikolaisen L, Rasmussen MB, Markager S, Olesen B, Arias C, Jensen PD (2011) Bioenergy potential of Ulva lactuca: Biomass yield, methane production and combustion. Bioresource Technol 102:2595-2604

Buermann CW, Oronsky AL, Horowitz MI (1979) Chondroitin sulfatedegrading enzymes in human polymorphonuclear leukocytes: characteristics and evidence for concerted mechanism. Arch Biochem Biophys 193:277-283

Cannell RJP, Dufresne C, Florence AJ, Gailliot FP, Gibbons S, Gray AI, Kinghorn AD, Kothandaraman S, Lee I-S, McAlpine J, Salituro GM, Shankland N, Shimizu Y, Silva GL, Stead P, VanMiddlesworth F, Venkat E, Verrall MS, Warr SRC, Wright AE (1998) Natural products isolation. In: Cannell RJP (ed) Methods in biotechnology, vol 4. Humana Press, Totowa, pp 343-408

Castro R, Zarra I, Lamas J (2004) Water-soluble seaweed extracts modulate the respiratory burst activity of turbot phagocytes. Aquaculture 229:67-78

Castro R, Piazzon MC, Zarra I, Leiro J, Noya M, Lamas J (2006) Stimulation of turbot phagocytes by Ulva rigida C. Agardh polysaccharides. Aquaculture 254:9-20

Castro R, Piazzon MC, Noya M, Leiro JM, Lamas J (2008) Isolation and molecular cloning of a fish myeloperoxidase. Mol Immunol 45:428-437

Castro-González MI, Romo FPG, Pérez-Estrella S, Carrillo-Domínguez S (1996) Chemical composition of the green alga Ulva lactuca. Cienc Mar 22:205-213

Charlier RH, Morand P, Finkl CW, Thys A (2007) Green tides on the Brittany Coasts. Environ Res Eng Manag 3:52-59

Chattopadhyay K, Mandal P, Lerouge P, Driouich A, Ghosal P, Ray B (2007) Sulphated polysaccharides from Indian samples of Enteromorpha compressa (Ulvales, Chlorophyta): isolation and structural features. Food Chem 104:928-935

Chuda Y, Ohnishi-Kameyama M, Nagata T (1997) Identification of the forms of boron in seaweed by ${ }^{11} \mathrm{~B}$ NMR. Phytochemistry 46:209213

Cluzet S, Torregrosa C, Jacquet C, Lafitte C, Fournier J, Mercier L, Salamagne S, Briand X, Esquerre-Tugaye MT, Dumas B (2004) Gene expression profiling and protection of Medicago truncatula against a fungal infection in response to an elicitor from green algae Ulva spp. Plant Cell Environ 27:917-928

Conrad HE (1980) The acid lability of the glycosidic bonds of Liduronic acid residues in glycosaminoglycans. Biochem $\mathrm{J}$ 191:355-363

Correlo VM, Costa-Pinto AR, Sol P, Covas JA, Bhattacharya M, Neves NM, Reis RL (2010) Melt processing of chitosan-based fibers and fiber-mesh scaffolds for the engineering of connective tissues. Macromol Biosci 10:1495-1504

Costa LS, Fidelis GP, Cordeiro SL, Oliveira RM, Sabry DA, Câmara RBG, Nobre LTDB, Costa MSSP, Almeida-Lima J, Farias EHC, Leite EL, Rocha HAO (2010) Biological activities of sulfated polysaccharides from tropical seaweeds. Biomed Pharmacother 64:21-28

Costa C, Alves A, Pinto P, Sousa RA, Silva E, Reis RL, Rodrigues A (2012) Characterization of ulvan extracts to assess the effect of different steps in the extraction procedure. Carbohyd Polym 88:537-546

Costa-Pinto AR, Reis RL, Neves NM (2011) Scaffolds based bone tissue engineering: the role of chitosan. Tissue Eng Pt B-Rev $17: 331-347$

Courtois J (2009) Oligosaccharides from land plants and algae: production and applications in therapeutics and biotechnology. Curr Opin Microbiol 12:261-273

Cruz DMG, Ivirico JLE, Gomes MM, Ribelles JLG, Sánchez MS, Reis RL, Mano JF (2008) Chitosan microparticles as injectable scaffolds for tissue engineering. J Tissue Eng Regen M $2: 378-380$

d'Ayala G, Malinconico M, Laurienzo P (2008) Marine derived polysaccharides for biomedical applications: chemical modification approaches. Molecules 13:2069-2106

Daniels BA (2004a) Seaweed extract composition for retardation of cardiovascular disorders and preservation of healthy cardiovascular function. US Patent US 2004/0170645 (2 September 2004) 
Daniels BA (2004b) Seaweed extract composition for treatment of diabetes and diabetic complications. PCT Patent WO 2004/ 103280 (2 December 2004)

De la Fuente M, Hernanz A, Viniegra S, Miquel J (2011) Sulfurcontaining antioxidants increase in vitro several functions of lymphocytes from mice. Int Immunopharmacol 11:661-669

de Reviers B, Leproux A (1993) Characterization of polysaccharides from Enteromorpha intestinalis (L.) Link, Chlorophyta. Carbohyd Polym 22:253-259

Delattre C, Michaud P, Keller C, Elboutachfaiti R, Beven L, Courtois B, Courtois J (2006) Purification and characterization of a novel glucuronan lyase from Trichoderma sp. GL2. Appl Microbiol Biot 70:437-443

Demais H, Brendle J, Deit HL, Laza AL, Lurton L, Brault D (2006) Interspersed clay. PCT Patent WO 2006/030075 (23 March 2006)

Devaki T, Sathivel A, BalajiRaghavendran HR (2009) Stabilization of mitochondrial and microsomal function by polysaccharide of Ulva lactuca on D-Galactosamine induced hepatitis in rats. Chem-Biol Interact 177:83-88

Durand M, Beaumatin P, Bulman B, Bernalier A, Grivet JP, Serezat M, Gramet G, Lahaye M (1997) Fermentation of green alga sealettuce (Ulva sp) and metabolism of its sulphate by human colonic microbiota in a semi-continuous culture system. Reprod Nutr Dev 37:267-283

El-Baky HHA, Baz FKE, Baroty GSE (2009) Potential biological properties of sulphated polysaccharides extracted from the macroalgae Ulva lactuca L. Acad J Cancer Res 2:01-11

Elboutachfaiti R, Pheulpin P, Courtois B, Courtois-Sambourg J (2010) Method for enzyme cleavage of polysaccharides derived from green algae. US Patent US 2010/0261894 (14 October 2010)

Elboutachfaiti R, Delattre C, Petit E, Michaud P (2011) Polyglucuronic acids: structures, functions and degrading enzymes. Carbohyd Polym 84:1-13

Ertesvag H, Valla S (1998) Biosynthesis and applications of alginates. Polym Degrad Stabil 59:85-91

Faury G, Molinari J, Rusova E, Mariko B, Raveaud S, Huber P, Velebny V, Robert AM, Robert L (2011) Receptors and aging: structural selectivity of the rhamnose-receptor on fibroblasts as shown by $\mathrm{Ca}^{2+}$-mobilization and gene-expression profiles. Arch Gerontol Geriat 53:106-112

Fialho AM, Moreira LM, Granja AT, Popescu AO, Hoffmann K, SáCorreia I (2008) Occurrence, production, and applications of gellan: current state and perspectives. Appl Microbiol Biot 79:889-900

France M (2009) Methods and compositions for treating hot flashes. PCT Patent WO 2009/142745 (26 November 2009)

Freitas MBD, Stadnik MJ (2012) Race-specific and ulvan-induced defense responses in bean (Phaseolus vulgaris) against Colletotrichum lindemuthianum. Physiol Mol Plant Pathol 78:8-13

Ghisalberti C (2010) Enhanced treatment of joint and connective tissue damage. PCT Patent WO 2010/109256 (30 September 2010)

Gosselin CC, Holt A, Lowe PA (1964) Polysaccharides of Enteromorpha species. J Chem Soc:5877-5880

Grenha A, Gomes ME, Rodrigues M, Santo VE, Mano JF, Neves NM, Reis RL (2009) Development of new chitosan/carrageenan nanoparticles for drug delivery applications. J Biomed Mater Res A 92A:1265-1272

Harada N, Maeda M (1998) Chemical structure of antithrombin-active rhamnan sulfate from Monostrom nitidum. Biosci Biotechnol Biochnol 62:1647-1652

Hayden HS, Blomster J, Maggs CA, Silva PC, Stanhope MJ, Waaland JR (2003) Linnaeus was right all along: Ulva and Enteromorpha are not distinct genera. Eur J Phycol 38:277-294

Hernández-Garibay E, Zertuche-González J, Pacheco-Ruíz I (2010) Isolation and chemical characterization of algal polysaccharides from the green seaweed Ulva clathrata (Roth) C. Agardh. J Appl Phycol 23:537-542

Jani GK, Shah DP, Prajapati VD, Jain VC (2009) Gums and mucilages: versatile excipients for pharmaceutical formulations. Asian J Pharm Sci 4:309-323

Jaulneau V, Lafitte C, Jacquet C, Fournier S, Salamagne S, Briand X, Esquerré-Tugayé M-T, Dumas B (2010) Ulvan, a sulfated polysaccharide from green algae, activates plant immunity through the jasmonic acid signaling pathway. J Biomed Biotechnol 2010:111. doi:10.1155/2010/525291

Jensen A (1993) Present and future needs for algae and algal products. Hydrobiologia 260/261:15-23

Jiao G, Yu G, Zhang J, Ewart HS (2011) Chemical structures and bioactivities of sulfated polysaccharides from marine algae. Mar Drugs 9:196-223

Kaeffer B, Benard C, Lahaye M, Blottiere HM, Cherbut C (1999) Biological properties of ulvan, a new source of green seaweed sulfated polysaccharides, on cultured normal and cancerous colonic epithelial tells. Planta Med 65:527-531

Khotimchenko YS, Khozhaenko EV, Khotimchenko MY, Kolenchenko EA, Kovalev VV (2010) Carrageenans as a new source of drugs with metal binding properties. Mar Drugs 8:1106-1121

Kim SK, Ravichandran YD, Khan SB, Kim YT (2008) Prospective of the cosmeceuticals derived from marine organisms. Biotechnol Bioproc Eng 13:511-523

Kitada K, Machmudah S, Sasaki M, Goto M, Nakashima Y, Kumamoto $\mathrm{S}$, Hasegawa $\mathrm{T}$ (2008) Supercritical $\mathrm{CO}_{2}$ extraction of pigment components with pharmaceutical importance from Chlorella vulgaris. J Chem Technol Biot 84:657-661

Kreisman LSC, Friedman JH, Neaga A, Cobb BA (2007) Structure and function relations with a T-cell-activating polysaccharide antigen using circular dichroism. Glycobiology 17:46-55

Kuda T, Ikemori T (2009) Minerals, polysaccharides and antioxidant properties of aqueous solutions obtained from macroalgal beachcasts in the Noto Peninsula, Ishikawa, Japan. Food Chem 112:575-581

Lahaye M (1991) Marine algae as sources of fibres: determination of soluble and insoluble dietary fibre contents in some sea vegetables. J Sci Food Agr 54:587-594

Lahaye M (1998) NMR spectroscopic characterisation of oligosaccharides from two Ulva rigida ulvan samples (Ulvales, Chlorophyta) degraded by a lyase. Carbohyd Res 314:1-12

Lahaye M (2001) Chemistry and physico-chemistry of phycocolloids. Cah Biol Mar 42:137-157

Lahaye M, Axelos MAV (1993) Gelling properties of water-soluble polysaccharides from proliferating marine green seaweeds (Ulva spp.). Carbohyd Polym 22:261-265

Lahaye M, Jegou D (1993) Chemical and physical-chemical characteristics of dietary fibres from Ulva lactuca (L.) Thuret and Enteromorpha compressa (L.) Grev. J Appl Phycol 5:195-200

Lahaye M, Ray B (1996) Cell-wall polysaccharides from the marine green alga Ulva rigida (Ulvales, Chlorophyta) - NMR analysis of ulvan oligosaccharides. Carbohyd Res 283:161-173

Lahaye M, Robic A (2007) Structure and functional properties of ulvan, a polysaccharide from green seaweeds. Biomacromolecules 8:17651774

Lahaye M, Jegou D, Buleon A (1994) Chemical characteristics of insoluble glucans from the cell wall of the marine green alga Ulva lactuca (L.) Thuret. Carbohyd Res 262:115-125

Lahaye M, Brunel M, Bonnin E (1997) Fine chemical structure analysis of oligosaccharides produced by an ulvan-lyase degradation of the water-soluble cell-wall polysaccharides from Ulva sp. (Ulvales, Chlorophyta). Carbohyd Res 304:325-333

Lahaye M, Inizan F, Vigoureux J (1998) NMR analysis of the chemical structure of ulvan and of ulvan-boron complex formation. Carbohyd Polym 36:239-249 
Lahaye M, Cimadevilla EA-C, Kuhlenkamp R, Quemener B, Lognoné V, Dion P (1999) Chemical composition and ${ }^{13} \mathrm{C}$ NMR spectroscopic characterisation of ulvans from Ulva (Ulvales, Chlorophyta). J Appl Phycol 11:1-7

Larraz E, Elvira C, Fernandez M, Parra J, Collia F, Lopez-Bravo A, Roman JS (2007) Self-curing acrylic formulations with applications in intervertebral disk restoration: drug release and biological behaviour. J Tissue Eng Regen M 1:120-127

Lazaridou A, Biliaderis CG, Micha-Screttas M, Steele BR (2004) A comparative study on structure-function relations of mixedlinkage (1-3), (1-4) linear $\beta$-D-glucans. Food Hydrocolloid 18:837-855

Leiro JM, Castro R, Arranz JA, Lamas J (2007) Immunomodulating activities of acidic sulphated polysaccharides obtained from the seaweed Ulva rigida C. Agardh. Int Immunopharmacol 7:879888

Linhardt RJ, Galliher PM, Cooney CL (1986) Polysaccharide lyases. Appl Biochem Biotechnol 12:135-176

Love J, Percival E (1964) Polysaccharides of green seaweed Codium fragile. 2. Water-soluble sulphated polysaccharides. J Chem Soc:3338-3345

Luque de Castro MD, Garcia-Ayuso LE (1998) Soxhlet extraction of solid materials: an outdated technique with a promising innovative future. Anal Chim Acta 369:1-10

Maeda M, Uehara T, Takeshita M (1992) Polysaccharide composition or polysaccharide having heparinoid activity, process for producing the same, and anticoagulant containing the same as active agent. Patent EP 0475383 (18 March 1992)

Mano JF, Silva GA, Azevedo HS, Malafaya PB, Sousa RA, Silva SS, Boesel LF, Oliveira JM, Santos TC, Marques AP, Neves NM, Reis RL (2007) Natural origin biodegradable systems in tissue engineering and regenerative medicine: present status and some moving trends. J Roy Soc Interface 4:999-1030

Mao W, Zang X, Li Y, Zhang H (2006) Sulfated polysaccharides from marine green algae Ulva conglobata and their anticoagulant activity. J Appl Phycol 18:9-14

Massarelli I, Murgia L, Bianucci AM, Chiellini F, Chiellini E (2007) Understanding the selectivity mechanism of the human asialoglycoprotein receptor (ASGP-R) toward gal- and man-type ligands for predicting interactions with exogenous sugars. Int J Mol Sci 8:13-28

Matsuo K-SY (2004) Novel chemical substance having morphogenetic and growth-accelerating activities. US Patent US 2004/0228854 (18 November 2004)

McKinnell JP, Percival E (1962a) Acid polysaccharide from green seaweed, Ulva lactuca. J Chem Soc:2082-2083

McKinnell JP, Percival E (1962b) Structural investigations on watersoluble polysaccharide of green seaweed Enteromorpha compressa. J Chem Soc:3141-3148

Mejía-Teniente L, Torres-Pacheco I, González-Chavira MM, OcampoVelazquez RV, Herrera-Ruiz G, Chapa-Oliver AM, GuevaraGonzález RG (2010) Use of elicitors as an approach for sustainable agriculture. Afr J Biotechnol 9:9155-9162

Michaud P, Costa AD, Courtois B, Courtois J (2003) Polysaccharide lyases: recent developments as biotechnological tools. Crit Rev Biotechnol 23:233-266

Michel C, Macfarlane GT (1996) Digestive fates of soluble polysaccharides from marine macroalgae: involvement of the colonic microflora and physiological consequences for the host. J Appl Bacteriol 80:349-369

Montealegre JR, López C, Stadnik MJ, Henríquez JL, Herrera R, Polanco R, Piero RMD, Pérez LM (2010) Control of grey rot of apple fruits by biologically active natural products. Trop Plant Pathol 35:271-276

Morand P, Briand X (1996) Excessive growth of macroalgae: a symptom of environmental disturbance. Bot Mar 39:491-516
Morelli A, Chiellini F (2010) Ulvan as a new type of biomaterial from renewable resources: functionalization and hydrogel preparation. Macromol Chem Phys 211:821-832

Msuya F, Neori A (2008) Effect of water aeration and nutrient load level on biomass yield, $\mathrm{N}$ uptake and protein content of the seaweed Ulva lactuca cultured in seawater tanks. J Appl Phycol 20:1021-1031

Muto S, Niimura K, Oohara M, Oguchi Y, Matsunaga K, Hirose K, Kakuchi J, Sugita N, Furusho T, Yoshikumi C, Takahashi M (1992) Polysaccharides and antiviral drugs containing the same as active agent. US Patent US 5089481 (18 February 1992)

O'Mara AM, O'Mara BJ (2009) Detoxification composition and method of detoxifying the body. US Patent US 2009/0060942 (5 March 2009)

Oakes JM, Eyre BD, Middelburg JJ, Boschker HTS (2010) Composition, production, and loss of carbohydrates in subtropical shallow subtidal sandy sediments: rapid processing and long-term retention revealed by ${ }^{13} \mathrm{C}$-labeling. Limnol Oceanogr 55:2126-2138

Oliveira JT, Reis RL (2011) Polysaccharide-based materials for cartilage tissue engineering applications. J Tissue Eng Regen M 5:421-436

Ortiz J, Romero N, Robert P, Araya J, Lopez-Hernandez J, Bozzo C, Navarrete E, Osorio A, Rios A (2006) Dietary fiber, amino acid, fatty acid and tocopherol contents of the edible seaweeds Ulva lactuca and Durvillaea antarctica. Food Chem 99:98-104

Ovodov YS (1975) The chemistry of glycuronoglycans. Chem Nat Compd 3:300-315

Paradossi G, Cavalieri F, Pizzoferrato L, Liquori AM (1999) A physico-chemical study on the polysaccharide ulvan from hot water extraction of the macroalga Ulva. Int J Biol Macromol 25:309-315

Paradossi G, Cavalieri F, Chiessi E (2002) A conformational study on the algal polysaccharide ulvan. Macromolecules 35:6404-6411

Paulert R, Talamini V, Cassolato JEF, Duarte MER, Noseda MD, Smania A Jr, Stadnik MJ (2009) Effects of sulfated polysaccharide and alcoholic extracts from green seaweed Ulva fasciata on anthracnose severity and growth of common bean (Phaseolus vulgaris L.). J Plant Dis Protect 116:263-270

Pengzhan Y, Ning L, Xiguang L, Gefei Z, Quanbin Z, Pengcheng L (2003a) Antihyperlipidemic effects of different molecular weight sulfated polysaccharides from Ulva pertusa (Chlorophyta). Pharmacol Res 48:543-549

Pengzhan Y, Quanbin Z, Ning L, Zuhong X, Yanmei W, Zhi'en L (2003b) Polysaccharides from Ulva pertusa (Chlorophyta) and preliminary studies on their antihyperlipidemia activity. J Appl Phycol 15:21-27

Percival E, Wold JK (1963) Acid polysaccharide from green seaweed Ulva lactuca. 2. Site of ester sulphate. J Chem Soc:5459-5468

Pereira RC, Scaranari M, Castagnola P, Grandizio M, Azevedo HS, Reis RL, Cancedda R, Gentili C (2009) Novel injectable gel (system) as a vehicle for human articular chondrocytes in cartilage tissue regeneration. J Tissue Eng Regen M 3:97-106

Pomponi SA (1999) The bioprocess-technological potential of the sea. J Biotechnol 70:5-13

Popa EG, Gomes ME, Reis RL (2011) Cell delivery systems using alginate-carrageenan hydrogel beads and fibers for regenerative medicine applications. Biomacromolecules 12:3952-3961

Popper ZA, Fry SC (2003) Primary cell wall composition of bryophytes and charophytes. Ann Bot 91:1-12

Popper ZA, Michel G, Hervé C, Domozych DS, Willats WGT, Tuohy MG, Kloareg B, Stengel DB (2011) Evolution and diversity of plant cell walls: from algae to flowering plants. Annu Rev Plant Biol 62:567-590

Qi H, Zhang Q, Zhao T, Chen R, Zhang H, Niu X, Li Z (2005a) Antioxidant activity of different sulfate content derivatives of polysaccharide extracted from Ulva pertusa (Chlorophyta) in vitro. Int J Biol Macromol 37:195-199 
Qi H, Zhao T, Zhang Q, Li Z, Zhao Z, Xing R (2005b) Antioxidant activity of different molecular weight sulfated polysaccharides from Ulva pertusa Kjellm (Chlorophyta). J Appl Phycol 17:527-534

Qi H, Zhang Q, Zhao T, Hu R, Zhang K, Li Z (2006) In vitro antioxidant activity of acetylated and benzoylated derivatives of polysaccharide extracted from Ulva pertusa (Chlorophyta). Bioorg Med Chem Lett 16:2441-2445

Qi H, Liu X, Ma J, Zhang Q, Li Z (2010) In vitro antioxidant activity of acetylated derivatives of polysaccharide extracted from Ulva pertusa (Cholorophta). J Med Plants Res 4:2445-2451

Quemener B, Lahaye M, Bobin-Dubigeon C (1997) Sugar determination in ulvans by a chemical-enzymatic method coupled to high performance anion exchange chromatography. J Appl Phycol 9:179-188

Ranson M, Gutierrez G, Brault D, Le Deit H, Pages-Xatart-Pares X, Alfos C (2007) Product resulting from grafting of fatty chains to ulvans and use of said product as a surfactant. PCT Patent WO 2007/045795 (26 April 2007)

Ray B (2006) Polysaccharides from Enteromorpha compressa: isolation, purification and structural features. Carbohyd Polym 66:408-416

Ray B, Lahaye M (1995a) Cell-wall polysaccharides from the marine green alga Ulva rigida (Ulvales, Chlorophyta). Chemical structure of ulvan. Carbohyd Res 274:313-318

Ray B, Lahaye M (1995b) Cell-wall polysaccharides from the marine green alga Ulva rigida (Ulvales, Chlorophyta). Extraction and chemical composition. Carbohyd Res 274:251-261

Renn DW (1984) Agar and agarose: indispensable partners in biotechnology. Ind Eng Chem Res Dev 23:17-21

Robic A, Sassi JF, Lahaye M (2008) Impact of stabilization treatments of the green seaweed Ulva rotundata (Chlorophyta) on the extraction yield, the physico-chemical and rheological properties of ulvan. Carbohyd Polym 74:344-352

Robic A, Gaillard C, Sassi J-F, Lerat Y, Lahaye M (2009a) Ultrastructure of ulvan: a polysaccharide from green seaweeds. Biopolymers 91:652-664

Robic A, Rondeau-Mouro C, Sassi JF, Lerat Y, Lahaye M (2009b) Structure and interactions of ulvan in the cell wall of the marine green algae Ulva rotundata (Ulvales, Chlorophyceae). Carbohyd Polym 77:206-216

Robic A, Sassi J-F, Dion P, Lerat Y, Lahaye M (2009c) Seasonal variability of physicochemical and rheological properties of ulvan in two Ulva species (Chlorophyta) from the Brittany Coast. J Phycol 45:962-973

Rochet V, Bernalier A (1997) Utilization of algal polysaccharides by human colonic bacteria, in axenic culture or in association with hydrogenotrophic microorganisms. Reprod Nutr Dev 37:221-229

Santo VE, Frias AM, Carida M, Cancedda R, Gomes ME, Mano JF, Reis RL (2009) Carrageenan-based hydrogels for the controlled delivery of PDGF-BB in bone tissue engineering applications. Biomacromolecules 10:1392-1401

Santos TC, Marques AP, Silva SS, Oliveira JM, Mano JF, Castro AG, Reis RL (2007) In vitro evaluation of the behaviour of human polymorphonuclear neutrophils in direct contact with chitosanbased membranes. J Biotechnol 132:218-226

Sathivel A, BalajiRaghavendran HR, Srinivasan P, Devaki T (2008) Anti-peroxidative and anti-hyperlipidemic nature of Ulva lactuca crude polysaccharide on D-galactosamine induced hepatitis in rats. Food Chem Toxicol 46:3262-3267
Schijf J, Ebling AM (2010) Investigation of the ionic strength dependence of Ulva lactuca acid functional group pKas by manual alkalimetric titrations. Environ Sci Technol 44:1644-1649

Siddhanta AK, Goswami AM, Ramavat BK, Mody KH, Mairh OP (2001) Water soluble polysaccharides of marine algal species of Ulva (Ulvales, Chlorophyta) of Indian waters. Indian J Mar Sci 30:166-172

Silva SS, Duarte ARC, Carvalho AP, Mano JF, Reis RL (2011) Green processing of porous chitin structures for biomedical applications combining ionic liquids and supercritical fluid technology. Acta Biomater 7:1166-1172

Smit AJ (2004) Medicinal and pharmaceutical uses of seaweed natural products: a review. J Appl Phycol 16:245-262

Takemura KM, Iljima KM, Tateno OY, Okamoto N, Fuse M (1986) Process for preparing L-rhamnose. US Patent US 4758283 (19 July 1988)

Tavernier ML, Delattre C, Petit E, Michaud P (2008) $\beta$-(1,4)-polyglucuronic acids - an overview Open. Biotechnol J 2:73-86

Toskas G, Hund R-D, Laourine E, Cherif C, Smyrniotopoulos V, Roussis V (2011) Nanofibers based on polysaccharides from the green seaweed Ulva rigida. Carbohyd Polym 84:1093-1102

van Rooijen N, Sanders A (1997) Elimination, blocking, and activation of macrophages: three of a kind? J Leukocyte Biol 62:702-709

Warrand J (2006) Healthy polysaccharides - the next chapter in food products. Food Technol Biotechnol 44:355-370

Webster EA, Gadd GM (1996) Cadmium replaces calcium in the cell wall of Ulva lactuca. BioMetals 9:241-244

Webster EA, Murphy AJ, Chudek JA, Gadd GM (1997) Metabolismindependent binding of toxic metals by Ulva lactuca: cadmium binds to oxygen-containing groups, as determined by NMR. BioMetals 10:105-117

Weisberg E, Baumann L (2009) Cosmetic and drug regulation. In: Baumann L, Saghari S, Weisberg E (eds) Cosmetic dermatology, principles and practice, 2nd edn. McGraw-Hill, New York, pp 241-244

Wijesekara I, Pangestuti R, Kima S-K (2011) Biological activities and potential health benefits of sulfated polysaccharides derived from marine algae. Carbohyd Polym 84:14-21

Williams PA (2009) Molecular interactions of plant and algal polysaccharides. Struct Chem 20:299-308

Wong KH, Cheung PCK (2000) Nutritional evaluation of some subtropical red and green seaweeds: Part I-Proximate composition, amino acid profiles and some physico-chemical properties. Food Chem 71:475-482

Wood CG (1974) Seaweed extracts: a unique ocean resource. J Chem Educ 51:449-452

Xiong S, Hou D, Huang N (2010) Isolation and antioxidant activity of acidic polysaccharide with water-solubility from Prunella Vulgaris Linn. 4th International Conference on Bioinformatics and Biomedical Engineering (iCBBE), Chengdu, China:1-5

Yamamoto M (1980) Physicochemical studies on sulfated polysaccharides extracted from seaweeds at various temperatures. Agr Biol Chem Tokyo 44:589-593

Yang L, Zhang L-M (2009) Chemical structural and chain conformational characterization of some bioactive polysaccharides isolated from natural sources. Carbohyd Polym 76:349-361

Yapo BM (2011) Rhamnogalacturonan-I: a structurally puzzling and functionally versatile polysaccharide from plant cell walls and mucilages. Polym Rev 51:391-413

Zhang HJ, Mao WJ, Fang F, Li HY, Sun HH, Chen Y, Qi XH (2008) Chemical characteristics and anticoagulant activities of a sulfated polysaccharide and its fragments from Monostroma latissimum. Carbohyd Polym 71:428-434 